\title{
SISTEM INFORMASI EKSEKUTIF SEBARAN PENJUALAN KENDARAAN BERMOTOR RODA 2 DI KALIMANTAN TIMUR BERBASIS WEB
}

\author{
Priyo Sutopo'), Dedi Cahyadi'), Zainal Arifin ${ }^{3)}$
}

1,2,3) Jurusan Ilmu Komputer, Fakultas MIPA, Universitas Mulawarman

Jalan Barong Tongkok No. 4 Kampus Gunung Kelua Samarinda, Kalimantan Timur

E-Mail : priyo.sutopo@gmail.com ${ }^{1)}$,dedy.cahyadi@gmail.com ${ }^{2)}$, zainal_arifin@ @mipa.unmul.ac.id ${ }^{3)}$

\begin{abstract}
ABSTRAK
Pesatnya penjualan kendaraan bermotor roda 2 di Kalimantan timur sangat cepat, hal tersebut menimbulkan masalah pedataan kendaraan tersebut di masing-masing wilayah di Kalimantan timur, dalam hal ini eksekutif mengalami kesulitan dalam melihat penyajian data penjualan kendaraan bermotor atau grafik penjualan kendaraan, data yang di berikan untuk eksekutif hanyalah laporan manual dan mungkin sangat sulit dipahami, sehingga tidak efektif dan efisien, sehingga dibutuhkan sebuah aplikasi untuk membantu eksekutif dalam melihat penyajian data penjualan kendaraan bermotor dan grafik penjualan kendaraan. Aplikasi yang dapat memenuhi kebutuhan tersebut adalah sistem informasi eksekutif sebaran kendaraan bermotor roda 2 , Aplikasi yang mengegola sebaran penjualan kendaraan bermotor roda 2, Aplikasi ini memberikan kemudahan untuk para eksekutif, karena aplikasi ini berbasis web jadi dapat dilihat di mana pun, dan data yang di berikan selalu terbaru, sehingga mempermudah eksekutif mengambil keputusan untuk penjualan kendaraan bermotor.
\end{abstract}

Kata Kunci : Sistem Informasi, Sebaran Kendaraan Bermotor Roda

\section{PENDAHULUAN}

\subsection{Latar Belakang}

Dewasa ini, perkembangan bisnis di dunia usaha semakin berkembang pesat dan saling bersaing satu sama lain. Persaingan yang terjadi seiring dengan perkembangan teknologi informasi yang juga semakin berkembang pesat. Banyak perusahaan telah memanfaatkan sistem informasi demi mendukung kebutuhan bisnisnya. Sistem informasi tersebut harus terintegrasi secara baik, sehingga nantinya dapat menghasilkan data yang dapat diolah menjadi informasi yang berguna bagi perusahaanSetiap proses pendataan membutuhkan dukungan teknologi untuk membantu operasional, penyimpanan, pendataan. Sejauh ini, perusahaan telah menerapkan Teknologi Informasi untuk mendukung kegiatan bisnisnya, khususnya dalam proses penjualan dan distribusi produk.

Dalam penerapannya, sistem informasi tersebut masih bersifat semi otomatis. Proses secara semi otomatis tersebut dapat menyebabkan informasi yang dihasilkan masih kurang tepat karena faktor human error dan membutuhkan waktu yang lebih lama. Proses tersebut tentu saja tidak efektif bagi perusahaan karena memiliki cabang yang tersebar di banyak wilayah, dimana cabang- cabang tersebut mengolah data masingmasing secara terpisah. Hal ini mengakibatkan perusahaan mengalami kesulitan dalam menganalisis perkembangan bisnis, khususnya dalam penjualan dan distribusi produk untuk tiap wilayah yang berdampak pada kesulitan dalam menentukan keputusan yang strategis.
Berbagai permasalahan di atas memberi suatu pemikiran bagi penulis untuk merancang suatu sistem informasi penjualan dan distribusi produk berbasis Sistem Informasi yang nantinya dapat menjadi solusi nyata dan memberi pengaruh yang baik untuk distributor penjualan kendaraan bermotor roda 2. Secara teknis, sistem informasi penjualan dan distribusi produk berbasis Sistem Informasi menyajikan informasi yang mudah dilihat (eye catching) dan mudah dipahami. Hal ini akan membantu pihak manajemen dalam menganalisis informasi yang disajikan, sehingga memudahkan dalam pengambilan keputusan yang strategis bagi perusahaan. Hal inilah yang menjadi dasar penulis memilih judul. "Sistem Informasi Eksekutif Sebaran Penjualan Kendaraan Bermotor Roda 2 Di Kalimatan Timur“

\subsection{Rumusan Masalah}

Bagaimana membanggun suatu sistem informasi eksekutif sebaran penjualan kendaraan bermotor roda 2, agar mempermudah dalam pendataan kendaraan di beberapa kabupaten/kota yang ada di Kalimantan timur.

\subsection{Batasan Masalah}

Dalam batasan masalah peneliti dapat lebih menyerderhanakan dan mengarahkan penelitian agar tidak menyimpang dari apa yang diteliti, Batasan masalahnya adalah sebagai berikut :

1. Pendataan kendaraan berupa data mesin, type dan jenis.

2. Pendataan pembeli kendaraan. 
3. Sebaran di beberapa kabupaten/kota yang berada di Kalimantan imur.

\subsection{Manfaat}

Membantu perusahaan dalam menganalisa dalam perkembangan bisnis berdasarkan kondisi dari masing-masing wilayah, khususnya dalam distribusi dan penjualan produk serta perbandingan pencapaian penjualan sales marketingnya. Memudahkan dalam pengambilan keputusan yang strategis seperti penggurangan dan penambahan target penjualan dan pengadaan produk per wilayah secara cepat dan tepat, karena tersedianya data yang aktual dan dapat di gunakan setiap saat.

\section{DASAR TEORI}

\subsection{Definisi Sistem Informasi}

Menurut Siregar (2010:9) Computer Based Information System (CBIS) atau yang dalam Bahasa Indonesia disebut juga Sistem Informasi Berbasis Komputer merupakan sistem pengolah data menjadi sebuah informasi yang berkualitas dan dipergunakan untuk suatu alat bantu pengambilan keputusan. Sistem Informasi yang akurat dan efektif.

Secara teori, penerapan sebuah Sistem Informasi memang tidak harus menggunakan komputer dalam kegiatannya. Tetapi pada prakteknya tidak mungkin sistem informasi yang sangat kompleks itu dapat berjalan dengan baik jika tanpa adanya komputer. Sistem Informasi merupakan sistem pembangkit informasi. Dengan integrasi yang dimiliki antar subsistemnya, sistem informasi akan mampu menyediakan informasi yang berkualitas, tepat, cepat dan akurat sesuai dengan manajemen yang membutuhkannya.

\subsection{Definisi Data}

Menurut Siregar (2010:9) dalam kamus bahasa Inggris-Indonesia, data diterjemahkan sebagai istilah yang berasal dari kata "datum" yang berarti fakta atau bahan-bahan keterangan. Data merupakan deskripsi dari sesuatu dan kejadian yang kita hadapi. Data adalah fakta yang jelas lingkup, tempat, dan waktunya.

\subsection{Definisi Sistem}

Menurut Abidin (2010:7) Kata sistem berasal dari bahasa Latin (systema) dan bahasa Yunani (sustema) yang artinya adalah suatu kesatuan yang terdiri komponen atau elemen yang dihubungkan bersama untuk memudahkan aliran informasi, materi atau energi. Secara umum sistem adalah kumpulan dari beberapa bagian tertentu yang saling berhubungan secara harmonis untuk mencapai suatu tujuan tertentu. Elemen-elemen yang mewakili suatu sistem secara umum adalah masukan (input) pengolahan (processing) dan keluaran (output).
Menurut Jogiyanto (2005:3) Sistem mempunyai karakteristik atau sifat - sifat tertentu, yaitu :

1. Komponen Sistem

Suatu sistem terdiri dari sejumlah komponen yang saling berinteraksi, yang artinya saling bekerjasama membetuk satu kesatuan. Komponen-komponen sistem atau elemenelemen sistem dapat berupa suatu subsistem atau bagian-bagian dari sistem.

2. Batasan Sistem

Batas sistem merupakan daerah yang membatasi antara suatu sistem dengan sistem yang lainnya atau dengan lingkungan luarnya.

3. Lingkungan Luar Sistem

Lingkungan luar dari suatu sistem adalah apapun diluar batas dari sistem yang mempengaruhi operasi sistem.

4. Penghubung Sistem

Penghubung merupakan media penghubung antara satu subsistem dengan subsistem yang lainnya. Melalui penghubung ini memungkinkan sumber-sumber daya mengalir dari satu subsistem ke subsistem yang lainnya.

5. Masukan Sistem

Masukan (input) adalah energi yang dimasukkan ke dalam sistem. Masukan dapat berupa masukan perawatan (maintenance input) dan masukan sinyal (signal input).

6. Keluaran Sistem

Keluaran (output) adalah hasil dari energi yang diolah dan diklasifikasikan menjadi keluaran yang berguna dan sisa pembuangan.

7. Pengolahan Sistem

Suatu sistem dapat mempunyai suatu bagian pengolah yang akan merubah masukan menjadi keluaran.

8. Sasaran Sistem

Suatu sistem pasti mempunyai tujuan atau sasaran. Jika suatu sistem tidak mempunyai sasaran, maka operasi sistem tidak akan ada gunanya.

\subsection{Definisi Informasi}

Menurut Abidin (2010:9) Informasi adalah data yang diolah menjadi bentuk yang berguna dan menjadi berarti bagi penerimanya. Kegunaan informasi adalah untuk mengurangi ketidak pastian di dalam proses pengambilan keputusan tentang suatu keadaan. Suatu informasi dikatakan bernilai bila manfaatnya lebih efektif dibandingkan dengan biaya untuk mendapatkan informasi tersebut. Kualitas informasi sangat dipengaruhi atau ditentukan oleh beberapa hal yaitu :
1. Relevan (Relevancy)
2. Akurat (Accurancy)
3. Tepat waktu (Time liness)
4. Ekonomis (Economy)
5. Efisien (Efficiency)
6. Ketersediaan (Availability)
7. Dapat dipercaya (Reliability)
8. Konsisten 


\subsection{Komponen Sisten Informasi}

Menurut Jogiyanto (2005:1) dalam bukunya Analisis dan Desain Sistem Informasi, sistem informasi memiliki enam komponen yang dapat diklasifikasikan sebagai berikut :
1. Blok Masukan
2. Blok Model
3. Blok Keluaran
4. Blok Teknologi
5. Blok Basis Data
6. Blok Kendali

2.6. Kegiatan Sistem Informasi
1. Input
2. Proses
3. Output
4. Penyimpanan

\subsection{Definisi Internet}

Menurut Siregar (2010:12) Internet atau Interconnected Networking merupakan dua komputer atau lebih yang saling berhubungan membentuk jaringan komputer hingga meliputi jutaan komputer di dunia, yang saling berinteraksi dan bertukar informasi, terhadap masalah sosial misalnya dengan menggunakan alat-alat bantu online untuk mencapai bisnis elektronik (ecommerce), kepemilikan informasi dan interaksi dengan masyarakat.

Ada beberapa fasilitas dari internet yang sering kita temui bahkan digunakan antara lain :
1. E-mail
2. World Wide Web (WWW)
3. Newsgroup
4. Telnet
5. Chat
6. File Transfer Protocol (FTP)

\subsection{Definisi Web}

Web merupakan terobosan baru sebagai teknologi sistem informasi yang menghubungkan data dari banyak sumber dan layanan yang beragam macamnya di internet, Web cepat sekali populer di lingkungan pengguna internet, karena kemudahan yang diberikan kepada pengguna internet untuk melakukan penelusuran, penjelajahan, dan pencarian informasi.

\subsection{Definisi Web Server}

Menurut Siregar (2010:11) Web server adalah sebuah bentuk server yang khusus digunakan untuk menyimpan halaman website atau homepage. Komputer dapat dikatakan web server jika komputer tersebut memiliki suatu program server yang disebut Personal Web Server (PWS).

\subsection{Definisi PHP}

PHP adalah salah satu server side yang dirancang khusus untuk aplikasi web. PHP disisipkan diantara bahasa HTML dan karena bahasa server side, maka bahasa PHP akan dieksekusi di server, sehingga yang dikirimkan ke browser adalah hasil jadi dalam bentuk HTML, dan kode PHP tidak akan terlihat. PHP termasuk Open Source Product. Jadi, dapat diubah source code dan mendistribusikanya secara bebas.

\subsection{Definisi MySQL}

MySQL adalah salah satu jenis database server yang sangat terkenal. Kepopulerannya disebabkan MySQL menggunakan SQL sebagai bahasa dasar untuk mengakses databasenya. MySQL termasuk jenis RDBMS (Relational Database Management System). Pada MySQL, sebuah database mengandung satu atau sejumlah tabel. Tabel terdiri atas sejumlah baris dan setiap baris mengandung satu atau beberapa kolom.

\subsection{Definisi Basis Data (Database)}

Menurut Arifin (2010:3) Basisdata merupakan kumpulan dari data yang saling berhubungan antara satu dengan yang lain. Basis data atau database merupakan salah satu komponen yang penting dalam sistem informasi, karena berfungsi berfungsi sebagai basis penyedia informasi bagi pemakainya, Sistem basis data adalah suatu sistem informasi yang mengintegrasikan kumpulan dari data yang saling berhubungan dengan yang lainnya dan untuk membuatnya tersedia beberapa aplikasi yang bermacam-macam dalam suatu sistem organisasi. Sistem basis data adalah suatu sistem menyusun dan mengelola record-record menggunakan komputer untuk menyimpan atau merekam serta memelihara data operasional lengkap sebuah organisasi atau perusahaan sehingga mampu menyediakan informasi yang optimal yang diperlukan pemakai untuk proses mengambil keputusan.

\subsection{Definisi DFD (Data Flow Diagram)}

DFD adalah pengembangan diagram konteks yang terdiri atas proses-proses dimana setiap prosesnya diberi nomor bilangan bulat, umumnya di mulai dari sudut kiri atas diagram dan mengarah ke sudut sebelah kanan bawah (Kenneth, 2002). DFD sering digunakan untuk menggambarkan suatu sistem yang telah ada atau sistem baru yang akan dikembangkan secara logika tanpa mempertimbangkan lingkungan fisik dimana data tersebut mengalir atau lingkungan fisik dimana data tersebut akan disimpan (Jogianto, 1990).

\section{METODE PENELITIAN}

\subsection{Metode Pengumpulan Data}

Adapun metode pengumpulan data dan informasi yang digunakan selama kegiatan penelitian adalah studi pustaka yang dimaksudkan untuk mempelajari literatur atau referensi yang digunakan sebagai bahan masukkan, terutama sebagai tinjauan pustaka termasuk dasar teori dan lain-lain, Pengumpulan data tidak lain dari suatu proses pengadaan data primer untuk keperluan penelitian. Pengumpulan data merupakan langkah 
yang amat penting, karena pengumpulan data adalah prosedur yang sistematik dan standar untuk memperoleh data yang diperlukan.

\subsection{Tahap Analisis}

Tahap Analisis data merupakan bagian terpenting dalam penyusuan laporan penelitian ini dan juga dalam pembuatan sistem informasi nantinya, karena dengan analisis tersebut data dapat diberi arti dan makna yang berguna dalam pemecahan suatu permasalahan dalam penelitian tersebut. Untuk menjadikan sistem yang akan dikembangkan nantinya akan menjadi lebih baik dan maksimal serta memenuhi harapan dari pihak manajemen.

\subsection{Analisis Kebutuhan Sistem}

Analisis kebutuhan adalah merupakan bagian yang tidak bisa dipisahakan dari pengembangan sistem, dimana sistem informasi yang akan dibuat nantinya akan disesuailan dengan spesifikasi dan sistem-sistem pendukung lainya baik itu perangkat keras maupun perangkat lunak.

\subsection{Desain Sistem}

Adapun Penggunaan alat-alat bantu yang digunakan oleh peneliti dalam mendesain perangkat lunak tersebut adalah sebagai berikut :

1. Alur Dokumen (Flow Of Document / FOD).

2. Bagan Alur Data (Data Flow Diagram).

3. Bagan hubungan antar entitas (Entity RelationshipDiagram/ERD)

4. Desain Antarmuka Program (Interface Program Design)

\section{HASIL PENELITIAN DAN PEMBAHASAN}

\subsection{Perancangan Sistem}

Tahap ini menentukan konfigurasi yang dibutuhkan oleh sistem, mendesain atau merancang perangkat lunak yang termasuk didalamnya adalah proses, aturan yang digunakan, antarmuka pengguna dan inputan yang dibutuhkan.

\subsection{UseCase Diagram Pengelolaan File}

UseCase diagram menggambarkan apa saja aktifitas yang dilakukan oleh suatu sistem dari sudut pandang pengamatan luar. Dalam sistem informasi ini admin adalah pengelola sistem yang memiliki hak akses penuh terhadap semua fungsifungsi yang ada di aplikasi sistem informasi ini yang dapat ditunjukkan seperti pada gambar 4.1.

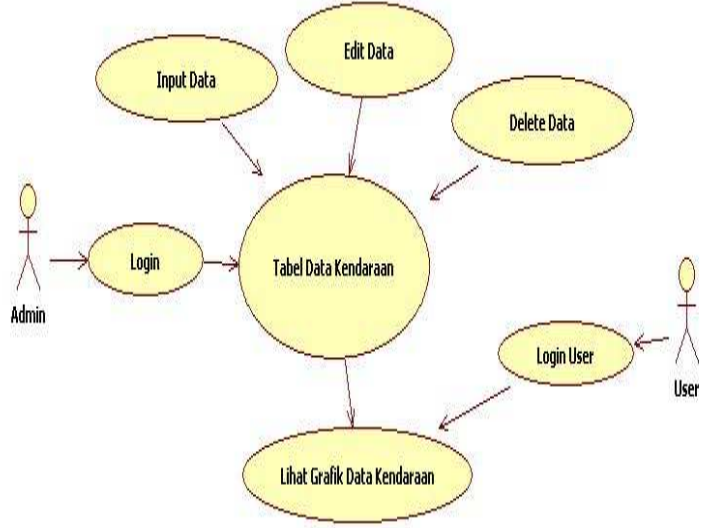

Gambar 4.1 Use Case Diagram Pengelolaan File

\subsection{Class Diagram Pengelolaan File}

Pada sistem informasi pengelompokan data kedaraan ini terdapat 6 buah class, dimana seluruh class saling terkait diantaranya adalah class merk, class type, class kota, class kecamatan, class keluarahan, dan class data. Relasi class tersebut dapat dilihat pada gambar 4.3.

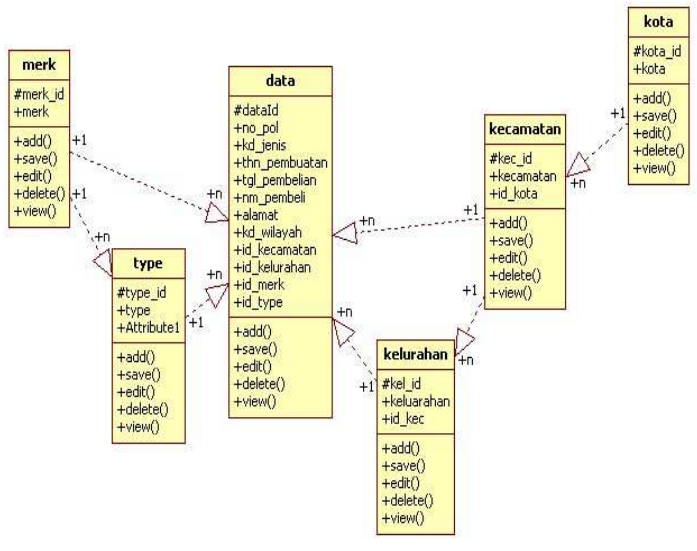

Gambar 4.3. Class Diagram Pengelolaan File

\subsection{Activity Diagram}

Activity diagram merupakan sebuah diagram yang menggambarkan sifat dinamis dari sebuah sistem dengan permodelan aliran control dari aktifitas ke aktifitas. Sebuah aktifitas merupakan operasi dari beberapa class pada sistem yang menghasilkan perubahan pada keadaan sistem, Alur activity diagram dapat dilihat pada gambar 4.4. 


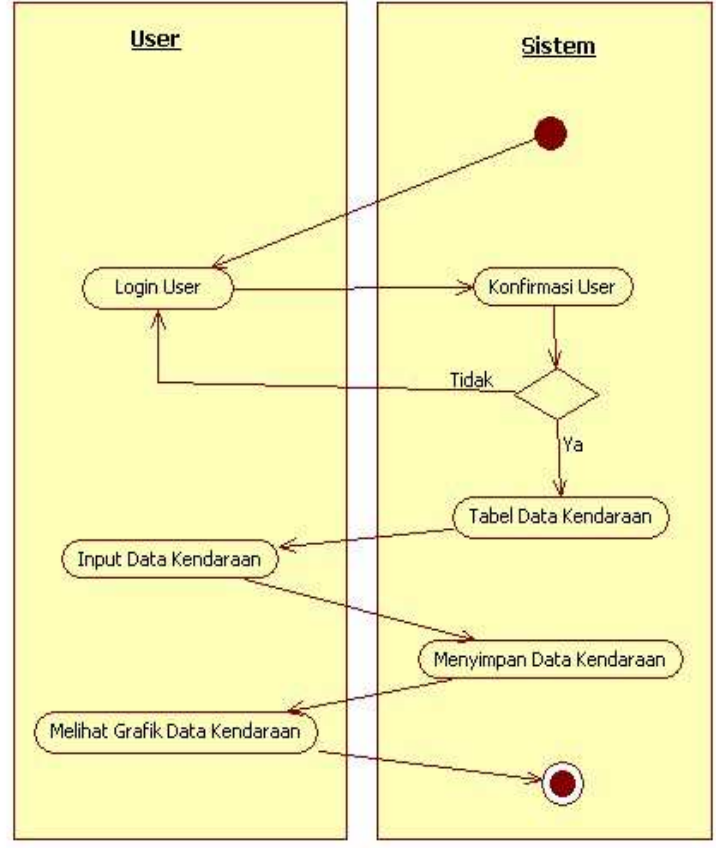

Gambar 4.4 Activity Diagram Penyimpanan Data Kendaraan

\subsection{Desain Antar Muka Aplikasi}

Di dalam sistem ini, terdapat beberapa menutampilan yang di dalam menu tersebut terdapat pula sub menu di dalamnya. Di bawah akan digambarkan bagaimana tampilan desain dari layar terminal/interface dari form login ke form input data kendaraan dan input data pendukung. Adapun form input data kendaraan dapat di lihat pada gambar 4.13, di dalam tabel ini admin akan menginputkan data pembelian kendaraan bermotor, setelah data di inputkan semua dan di simpan data akan di simpan ke dalam form data kendaraan, untuk gambar form data kendaraan dapat dilihat pada gambar 4.12.

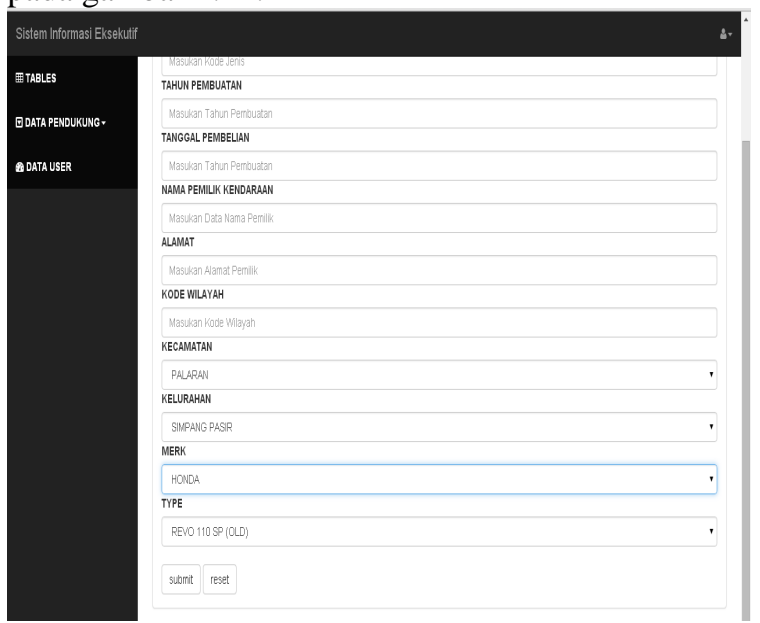

Gambar 4.13 Form Input Data Kendaraan

Pada form input data kota, admin diminta menginputkan data kalo ada kota yang ingin di masukan sebagai data pendukung, jadi kita bisa memasukkan nama kota yang baru, ada pun form input data kota bisa kita lihat pada gambar 4.18, setelah itu data akan di simpan ke dalam tabel data kota, adapun tampilan tabel data kota dapat dilihat pada gambar 4.17.

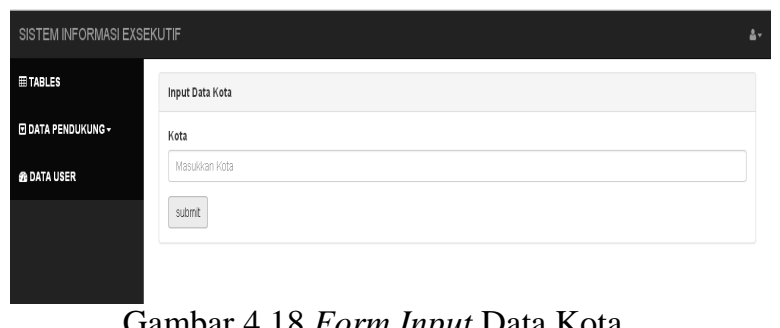

Pada form input data kecamatan, admin diminta menginputkan data kalo ada kecamatan yang ingin di masukan sebagai data pendukung, jadi kita bisa memasukkan nama kecamatan yang baru, sebelum menginputkan data kecamatan admin akan menginputkan data kota, karena data ini akan direlasikan agar mempermudah dalam penginputan kendaraan nantinya, ada pun form input data kecamatan bisa kita lihat pada gambar 4.22, setelah itu data akan di simpan ke dalam tabel data kecamatan, adapun tampilan tabel data kota dapat dilihat pada gambar 4.21.

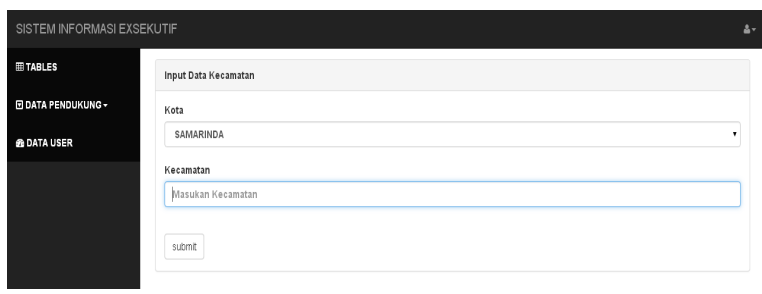

Gambar 4.22 Form Input Data Kecamatan

Pada form input data kelurahan, admin diminta menginputkan data kalo ada kelurahan yang ingin di masukan sebagai data pendukung, jadi kita bisa memasukkan nama kelurahan yang baru, sebelum menginputkan data kelurahan admin akan menginputkan data kecamatan, karena data ini akan direlasikan agar mempermudah dalam penginputan kendaraan nantinya, ada pun form input data kelurahan bisa kita lihat pada gambar 4.26, setelah itu data akan di simpan ke dalam tabel data kelurahan, adapun tampilan tabel data kota dapat dilihat pada gambar 4.25.

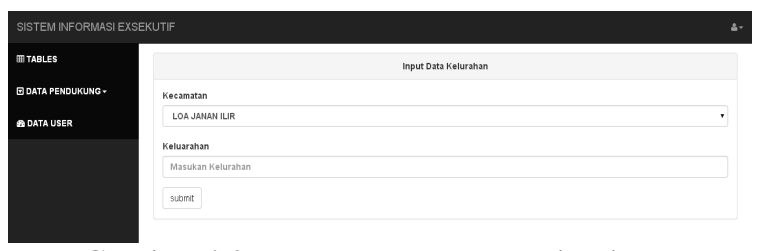

Gambar 4.26 Form Input Data Kelurahan

Selain data pendukung kota, kecamatan dan kelurahan, ada juga data pendukung merk kendaraan dan type kendaraan, data pendukung ini diperutuhkan apabila sewaktu-waktu ada merk motor baru, dan paling sering adalah type motor yang baru, dari sebab itu di buatkan form data 
pendukung merk dan type kendaraan. Adapun form input data merk kendaraan dapat kita lihat pada gambar 4.30, setelah itu data akan di simpan ke tabel data merk kendaraan yang bisa dilihat pada gambar 4.29.

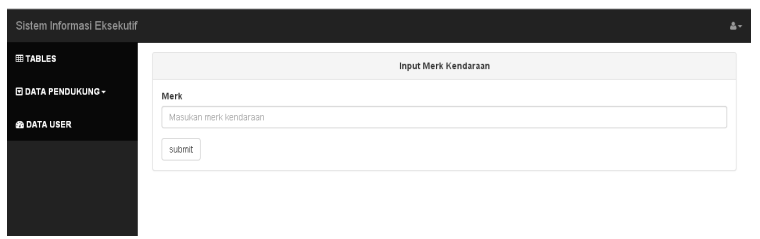

Gambar 4.30 Form Input Data Merk Kendaraan

Dalam form input data type kendaraan, admin diminta menginputkan data merk dan type kendaraan, data merk dan type akan direlasikan agar mempermudah dalam pencarian merk kendaraan, adapun gambar inputan data merk kendaraan dapat kita lihat pada gambar 4.34, dan data ada di simpan pada tabel data kendaraan, gambar tabel bisa dilihat pada gambar 4.33.

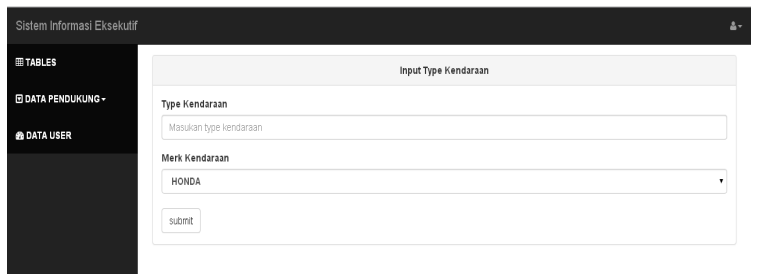

Gambar 4.34 Form Input Data Type Kendaraan

\section{PENUTUP}

\subsection{Kesimpulan}

Dari hasil penelitian dan pembahasan yang telah dijabarkan pada bab-bab sebelumnya mengenai program yang telah dibuat dapat diambil kesimpulan:

1. Telah dibangun Sistem Informasi Eksekutif Sebaran Penjualan Kendaraan Bermotor Roda 2 yang dapat digunakan sebagai alat bantu dalam penyampaian informasi penjualan kendaraan bermotor roda 2 di Kalimantan timut yang dapat di pergunakan dalam pengambilan keputusan untuk penjualan kendaraan bermotor di Kalimantan timur.

2. Permasalahan pendataan penjualan kendaraan bermotor di Kalimantan timur yang masih sulit untuk pendataanya. Hal tersebut dapat diatasi dengan menggunakan sistem informasi ini yang sengaja dibuat untuk mewujudkan kegiatan yang telah ada.

3. Solusi yang ditawarkan sistem ini tidak hanya dalam gambaran penulis, melainkan dari kebutuhan, kinerja dan waktu yang ada di lingkungan teknologi yang selalu berkembang setiap saat maka terwujudlah sistem informasi ini.

\subsection{Saran}

Mengenai semua dari apa yang telah di buat diatas, penulis memberikan saran sebagai berikut:

1 Karena teknologi menuntut setiap pekerjaan semua menjadi praktis, penggunaan sistem ini mestinya dapat langsung diterapkan sehingga mendapatkan tempat ditangan pengguna yang tepat.

2 Perlunya pengembangan sistem agar sistem yang telah dibuat dapat menjadi sistem informasi yang lebih baik lagi.

\section{DAFTAR PUSTAKA}

[1]. Siregar, 2010. Perancangan Portal Berbasis Web Dengan Menggunakan Php Dan MySQL Pada SMA Negeri 18 Medan, Sumatara utara

[2]. Abidin, Zaenal, 2010, Perancang Sistem Informasi Akademik pada Madrasah Aliyah Al-Istiqomah, unikom

[3]. Jogiyanto, H.M. 2005. Analisis dan Desain Sistem Informasi, Edisi ketiga, Cetakan pertama, Andi Offset, Yogyakarta.

[4]. Arifin, Zainal, 2010, Pembuatan Perangkat Lunak Aplikasi Pemesanan dan Penjualan Sepeda Motor, Jurnal Informatika Mulawarman

[5]. Kadir, Abdul, 2000. Konsep dan Tuntunan Praktis Basis Data, Andi Offset, Yogyakarta.

[6]. Tedjasutisna, Ating, 1995. Pemasaran. Armica. Bandung

[7]. Amsyah, Zulkifli, 2001. Manajemen Informasi Sistem, Gramedia Pustaka Umum, Jakarta

[8]. Leman., 1998. Metodologi Pengembangan Sistem Informasi, PT. Elekmedia Komputindo, Jakarta.

[9]. Marlinda, L. 2004. Sistem Basis Data. Yogyakarta 